\title{
A Call for More Diploma Nurses to Attain a Baccalaureate Degree Advancing the nursing profession in Oman
}

*Joy K. Kamanyire and Susan Achora

$$
\begin{aligned}
& \text { دعوة للممرضات اللواتي يكملن مؤهل الدبلوم لنيل درجة البكالوريوس } \\
& \text { النهوض بمهنة التمريض في عمان }
\end{aligned}
$$$$
\text { جوي كاباسيندي كمانيار و سوزان اكورا }
$$

\begin{abstract}
The healthcare needs of the Omani population are evolving, particularly with regards to changes in disease complexity, advances in technology and the enhanced delivery of healthcare services. Nurses now need to adapt to a fundamental shift in the provision of patient-centred care. In line with lifelong learning goals, registered nurses in Oman at the diploma level should seek to obtain a more advanced qualification, for instance a Bachelor of Science in Nursing, to ensure they possess the requisite skills and knowledge to keep abreast of new developments in healthcare management. Challenges involved in this transition and suggestions to overcome these potential obstacles are discussed in this article in order to inform nursing education stakeholders. Recommendations to ensure the success of bridging programmes are also suggested.
\end{abstract}

Keywords: Nursing; Clinical Competence; Patient Care; Baccalaureate Nursing Education; Nursing Diploma Program; Nursing Licensure; Oman.

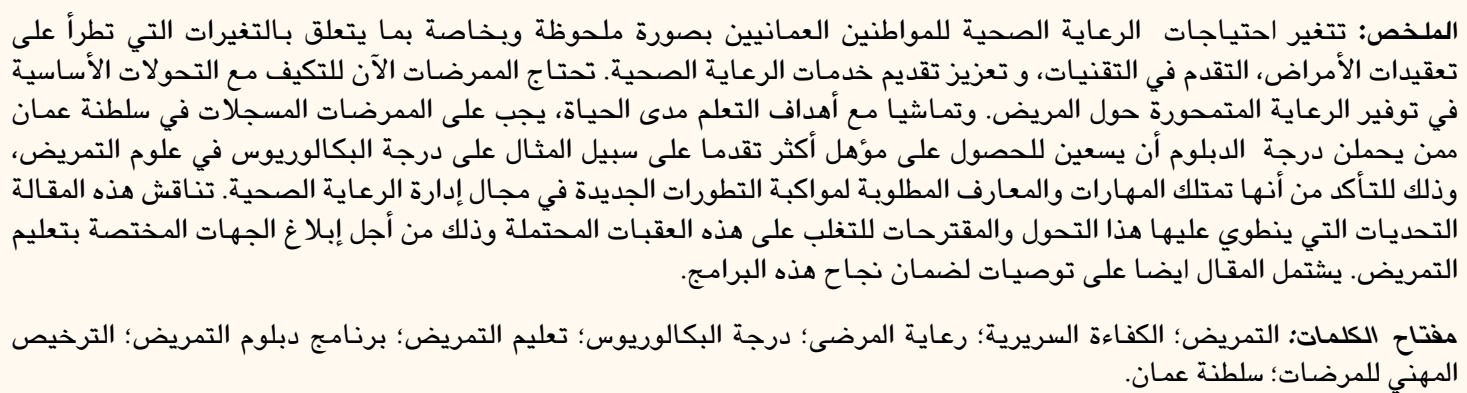

$\mathrm{O}$ VER THE LAST 40 YEARS, OMAN HAS undergone demographic, economic and social changes that have led to new epidemiological trends and a dramatic transformation of its health status over a short period of time. ${ }^{1}$ The healthcare needs of the expanding population are rapidly evolving, thus creating demands on the nursing workforce to offer commensurate healthcare services. Currently, the Omani population has an average life expectancy of 71.6 years, with $75 \%$ of the national disease burden due to non-communicable diseases (NCDs) and cardiovascular disease as the leading cause of death. ${ }^{1}$ Similar to other industrialised nations, common NCDs and risk factors in Oman include diabetes mellitus (12\%), being overweight (30\%) or obese (20\%), high cholesterol (41\%) and metabolic syndrome $(21 \%) .^{2}$
Primary healthcare $(\mathrm{PHC})$ is the backbone of healthcare delivery and the national Ministry of Health $(\mathrm{MOH})$ considers it the main entry point for all levels of care. ${ }^{3} \mathrm{PHC}$ is part of the national health policy based on the following principles: provision of comprehensive health services; equal distribution of health services among different population groups in line with their needs; involvement of the community in healthcare planning/implementation; and intersectorial collaboration with other health-related institutions to ensure a positive impact on community health. Individual PHC systems are based in wilayats (districts) or units of local administration and are key to ensuring free healthcare provision for all Omani nationals. ${ }^{1,3}$ District healthcare centres serve a local population of approximately 10-15 thousand with a team of doctors, nurses and support staff. ${ }^{4}$ 
Oman is faced with an increasing population of young and elderly people. ${ }^{3}$ Epidemiological, demographical and environmental health challenges necessitate changes to PHC implementation strategies, thereby requiring stronger links between regional health centres, the community and higher levels of care. Wider preventive and curative interventions are needed, with greater emphasis on injuries, mental health diseases, cancer, diabetes mellitus, human immunodeficiency virus/acquired immune deficiency syndrome, hypertension and lifestyle diseases like tobacco or drug abuse and obesity. ${ }^{3}$ These developments demand a review of the basic and continued training of PHC workers in their ability to manage complex NCDs. ${ }^{2}$

\section{Nursing in Oman}

The $\mathrm{MOH}$ is the largest employer of nurses in Oman, with approximately 10,394 registered nurses (RNs) in 2007; of these, 65\% were Omani nationals. ${ }^{5}$ The majority $(72 \%)$ of these nurses were diploma holders providing general nursing care. ${ }^{5}$ However, the $\mathrm{MOH}$ began implementing post-basic education programmes in selected nursing specialties in 1977 and opened the Oman Specialised Nursing Institute in 2001 to increase the number of nurses with specialised skills. ${ }^{6}$ By 2007, there were a total of 3,164 specialty nurses. ${ }^{5}$ Overall, few clinical nurses have a Bachelor of Science in Nursing (BSN) degree or an advanced degree. To date, Oman still faces a 30\% shortage of Omani nurses which is countered by employing expatriates on a fixed-term contractual basis. ${ }^{6}$ However, these nurses have short-term employment agreements with a subsequent high rate of staff turnover. This high turnover can lead to a shortage of nurses, further crippling the workforce and affecting healthcare delivery. The government of Oman has begun to support the nursing profession and ensure a sustainable human resource supply through the establishment and funding of nursing institutions and by offering free education to those pursuing nursing as a profession. ${ }^{6}$

There are 12 nursing institutions in Oman offering a three-year diploma programme and three universities offering a four-year BSN. Two universities offer RNto-BSN bridging programmes. In addition, the $\mathrm{MOH}$ sends nurses abroad to study for graduate degrees. ${ }^{5,6}$ By 2011, Oman had a total of 14,238 nurses serving a population of more than three million people. ${ }^{7}$ Despite this progress, there is still tremendous pressure for additional manpower due to the changing healthcare needs of the population and expansion of healthcare services in both public and private sectors. Additional health workers should encompass a larger scope of specialties and possess different skills, with expertise in counselling, health promotion, communication and community and home-based care. ${ }^{3}$

Shipman et al. reported that diploma holders may lack the necessary training to provide increasingly complex healthcare delivery due to their hospitalbased education in basic patient care. ${ }^{8}$ In a study of 414 nurses recruited from the four national referral hospitals in Oman, Ammouri et al. found that academic qualifications had a significant impact on evidence-based practice, with BSN nurses reporting fewer barriers to evidence-based research than diploma holders $\left(34.6 \%\right.$ versus $65.4 \%$, respectively). ${ }^{9}$ Furthermore, only $34.6 \%$ of nurses in this study held a baccalaureate degree in nursing; 9 this distribution of academic qualifications among nurses appears to be typical for most hospitals in Oman.

\section{Demand for a Baccalaureate Degree in the Nursing Profession}

Nursing continues to lag behind other professions with lower qualifications on average compared to other healthcare disciplines. ${ }^{10}$ Multiple entry points into the profession have further weakened its standing in a society that expects certain standards of the healthcare sector. ${ }^{11}$ Professionalism demands long-term and intensive academic preparation; compared to the fouryear BSN programme, the Associate Degree in Nursing (ADN) and similar diploma nursing programmes take only three years to complete. ${ }^{11,12}$ A crucial step in rebuilding the image of nursing professionalism would be to standardise the baccalaureate BSN degree as the only permissible entry point to a nursing career. ${ }^{11}$

Nursing has undergone a paradigm shift; the rapidly changing healthcare environment, increasingly complex diseases, advances in technology and a shift of care from hospital to community settings all require well-prepared nurses. ${ }^{8}$ The American Association of Colleges of Nursing (AACN) postulated that the massive shortage of nurses in the USA was due to a shortage of nurse educators. ${ }^{12,13}$ In 2013, approximately 78,089 qualified applicants for baccalaureate and graduate degrees in the USA were turned away, largely due to faculty shortages. ${ }^{13}$ There is a great need for baccalaureate- and graduate degree-educated nurses. ${ }^{11}$ The AACN recommends that all new nurses should complete a BSN degree within 10 years of licensure. ${ }^{12}$ 


\section{Upgrading Diploma-Level Education}

The World Health Organization reported that the provision of healthcare services continues to shift from hospital settings to focus on preventive care in the community. ${ }^{14}$ Nurses are now engaged in health promotion, disease prevention and case management, as well as traditional bedside nursing. ${ }^{15}$ Inevitably, there is a need for more qualified nurses and an education system that better prepares nurses to meet the complex demands of today's healthcare. ${ }^{16,17}$

Nursing baccalaureate programmes have been reported to equip nurses with critical thinking, leadership, care management and health promotion skills as well as the ability to work in a variety of inpatient and outpatient settings. ${ }^{11}$ BSN education covers all of the information provided in ADN and diploma courses, as well as in-depth courses in physical and social sciences, nursing research, public and community health and nursing management. These additional courses enrich the students' professional development and prepare nurses for a broader scope of practice with an improved understanding of the cultural, political and social issues that affect patients and influence healthcare delivery. ${ }^{12}$

Concerns have been raised that eliminating ADN and diploma level programmes will further worsen the already critical shortage of nurses. ${ }^{11}$ Nevertheless, the benefits of a baccalaureate education outweigh these concerns in terms of ensuring high-quality patient care. ${ }^{11}$ Studies have reported that baccalaureate nurses are associated with reduced patient mortality rates (e.g. approximately 3.6 deaths per 1,000 surgical patients) and shorter lengths of patient stay. ${ }^{18-20}$ These findings demonstrate that the level of nurse education directly influences patient outcomes. As Lane et al. observed, baccalaureate education can change the characteristics of the nursing workforce. ${ }^{11}$

However, not all RNs can meet the financial requirements of a baccalaureate education. ${ }^{11}$ The AACN encourages healthcare providers and employers to foster practice environments that embrace lifelong learning by offering incentives to RNs to pursue a BSN and higher degree qualifications. ${ }^{12}$ In addition, the lack of differentiation between various nursing qualifications in terms of acknowledgement, job description or salary was reported as a barrier for RNs to undertake BSN education. ${ }^{21}$ Hospitals and employers need to demonstrate their willingness to support baccalaureate nurses with clinical career ladders and financial incentives upon educational advancement. ${ }^{11}$ Baccalaureate nurses have been encouraged to seek out employers who recognise and value their level of education and distinct competencies. ${ }^{12}$ Additionally, employers should affirm their readiness to retain nurses upon completion of their BSN as a form of job security.

\section{Bridging Programmes}

$\mathrm{ADN}$ and diploma programmes are said to prepare 'technical' nurses, while the BSN programme prepares 'professional' nurses. ${ }^{22}$ RN-to-BSN bridging programmes are transitional programmes with additional courses designed to enhance upon the education offered in ADN or diploma programmes. ${ }^{23}$ Three critical elements that could help to foster this transition include: (1) an environment that promotes seamless academic progression; (2) teaching models that meet different learning needs; and (3) relevant content that prepares graduate nurses for practice. ${ }^{24}$ The National League for Nursing strongly advocates that RN-to-BSN bridging programmes provide different pathways for academic progression. ${ }^{25}$ There should be no additional prerequisite courses, but rather new courses that build on previous competencies and which are accessible and flexible, allowing for uninterrupted, individualised and independent learning.

\section{CURRICULUM MODEL}

RN-to-BSN bridging curricula should be developed in response to emerging healthcare needs; the model should build on concepts from the ADN/diploma programmes, be student-centred and faculty-facilitated and emphasise principles of adult learning. ${ }^{26}$ The core content in a BSN education should include health promotion, disease prevention, public health and health policy, with core competencies like evidencebased practice, leadership and professionalism. ${ }^{17} \mathrm{RN}$ to-BSN bridging programmes should seek to prepare nurses to work both in hospital and community settings, applying evidence-based research to practice and managing resources efficiently and effectively.

\section{CHALLENGES}

Higher institutions of learning have been advised to offer "efficient, academically sound, cost-effective and convenient" bridging programmes in order to encourage student enrolment and reduce attrition. ${ }^{27}$ Retaining students in these programmes is a challenge, as mature students may drop out if they cannot balance school and their career with home and family life. ${ }^{22}$ Boylston et al. found that RN-to-BSN students strongly believed that their families were their top priority and were willing to leave the programme when faced with a family crisis. ${ }^{27}$ Attrition rates of more 
than $25 \%$ have been reported in some institutions. ${ }^{28}$ Factors such as considerable tuition payments, lack of time to study, fear of failing, lack of recognition for past accomplishments, equal treatment of BSN and $\mathrm{ADN}$ or diploma nurses in the workplace and negative past educational experiences were reported to hinder RNs from pursuing a BSN education. ${ }^{21}$

\section{OVERCOMING RECRUITMENT AND ATTRITION CHALLENGES}

Education providers must develop innovative educational methods that foster career mobility, improve satisfaction and increase retention. Flexibility has been raised as a fundamental component to the success of bridging programmes, allowing students to study alongside other obligations. ${ }^{22}$ However, providing a flexible and comprehensive degree education has been reported as a challenge for faculty at some institutions. ${ }^{22}$ Specific acceleration bridging programmes have been developed for RNs and these have resulted in increased enrolment, decreased attrition rates and higher completion rates; online programmes have also been initiated to deal with accessibility and flexibility challenges. ${ }^{22}$ Furthermore, students have been reported to appreciate faculty support when educators acknowledge past experience, provide a caring environment and empower their students. ${ }^{29}$ In particular, RN students felt empowered when the faculty treated them as mature colleagues in the profession and acknowledged and built on past clinical experience during learning sessions. They also wished to be treated with empathy, especially when faced with family and social obligations. ${ }^{29}$ It has been found that RNs are more receptive to programmes that acknowledge them as working adults with multiple roles. ${ }^{25}$ According to Boylston et al., students reported greater satisfaction in bridging programmes with accessible services, flexible curricula and supportive faculties. ${ }^{22}$

Motivation to enrol in a bridging programme is paramount to the programme's success. RNs return to school for personal and professional development. ${ }^{30}$ However, this process can be perceived as both challenging and demotivating. A previous negative academic experience during the diploma programme may have a lasting traumatic effect on the decision to attain a BSN. ${ }^{21}$ Incorporating experiences from faculty who have gone through this programme would be beneficial to its restructuring. Urgent research is also needed to identify specific reasons why diploma nurses with more than 10 years of experience do not seek to attain BSN degrees.

\section{BRIDGING PROGRAMMES IN OMAN}

In the Omani setting, cultural and social factors may also play a role in the success of bridging programmes. As the ratio of female to male nurses in Oman is $7: 1,^{6}$ most bridging students would be female. According to Boylston et al., most RNs in their study were mature adult learners who were married with children and had numerous family obligations. ${ }^{22}$ In Oman, wives may need consent and the approval of their spouses to enrol or complete a programme. Omani women have been reported to have less social empowerment and autonomy in decision-making than men..$^{31,32}$ Experiences of graduates at the two universities which offer RN-BSN bridging programmes need to be explored. Bridging programmes implemented in Oman should be tailored to their unique social and cultural setting.

\section{Advancing the Nursing Profession in Oman}

Although Oman has made significant economic developments over the last four decades, the population has doubled in the span of 30 years with an increased prevalence of chronic diseases and an ageing population. ${ }^{3}$ These factors may jeopardise the quality of healthcare services. Quality improvements in nursing care can be realised by improving the academic standards of practising nurses. Greater emphasis on nursing qualifications, evidence-based practice and research and strategic leadership positions will improve the image of nursing in Oman. It seems inevitable that all RNs will eventually be required to upgrade to a BSN degree and that entry into the nursing workforce will stipulate a baccalaureate degree as a minimum requirement.

The most recent five-year strategic plan by the $\mathrm{MOH}$ in Oman has proposed that the BSN should be the minimum entry level for nursing practice. ${ }^{33}$ Oman plans to develop human resources in nursing and midwifery by focusing on leadership, continuous education and the provision of a safe and effective working environment. ${ }^{33}$ Providing diploma nurses with the necessary support to achieve a baccalaureate education would be one fundamental step towards helping Omani nurses pursue lifelong learning. ${ }^{11}$ Salary increments for BSN nurses and differentiation between nursing qualifications are also recommended. Efforts should be made to cultivate and promote nurse leaders who can join stakeholders in other health professions as full partners on advisory boards and in the planning of health policies and reforms to advance health systems and improve patient care. ${ }^{17}$ 


\section{Conclusion}

Due to recent changes in the health needs of the Omani population, diploma nurses should be encouraged to obtain a baccalaureate degree as part of their lifelong learning goals. This will help RNs maintain clinical competencies and meet the demands of a dynamic healthcare system. Education incentives for RNs to pursue a BSN should include differentiation of baccalaureate nurses from diploma nurses in terms of salary and job description. Furthermore, having a BSN degree should be the minimum entry point into the nursing profession. Seamless RN-toBSN transition programmes will improve the overall quality of nursing care and the image of the nursing profession in Oman. However, understanding the unique academic, cultural and social needs of Omani $\mathrm{RN}$-to-BSN bridging students is crucial.

\section{References}

1. Alshishtawy MM. Four decades of progress: Evolution of the health system in Oman. Sultan Qaboos Univ Med J 2010; 10:12-22.

2. Al-Lawati JA, Mabry R, Mohammed AJ. Addressing the threat of chronic diseases in Oman. Prev Chronic Dis 2008; 5:A99.

3. World Health Organization. Country cooperation strategy for WHO and Oman 2010-2015. From: www.applications.emro.who. int/docs/CCS_Oman_2010_EN_14485.pdf Accessed: Jan 2015.

4. World Health Organization. Health system profile: Oman. From: www.apps.who.int/medicinedocs/en/d/Is17304e Accessed: Jan 2015.

5. Ghosh B. Health workforce development planning in the Sultanate of Oman: A case study. Hum Resour Health 2009; 7:47. doi: 10.1186/1478-4491-7-47.

6. Minority Nurse. Professional nursing in Oman. From: www minoritynurse.com/professional-nursing-in-oman/ Accessed: Jan 2015.

7. Oman Ministry of Health. Health facts report 2011. From: www. moh.gov.om/en/web/statistics/-/health-facts-report-2011 Accessed: Jan 2015

8. Shipman D, Hooten J. Employers prefer BSN nurses: But where's the financial compensation? Nurse Educ Today 2010; 30:105-6. doi: 10.1016/j.nedt.2009.09.015.

9. Ammouri AA, Raddaha AA, Dsouza P, Geethakrishnan R, Noronha JA, Obeidat AA, et al. Evidence-based practice: Knowledge, attitudes, practice and perceived barriers among nurses in Oman. Sultan Qaboos Univ Med J 2014; 14:e537-45.

10. Nelson MA. Education for professional nursing practice: Looking backward into the future. Online J Issues Nurs $2002 ; 7: 4$

11. Lane SH, Kohlenberg E. The future of baccalaureate degrees for nurses. Nurs Forum 2010; 45:218-27. doi: 10.1111/j.17446198.2010.00194.x.

12. American Association of Colleges of Nursing. Fact sheet: The impact of education on nursing practice. From: www.aacn. nche.edu/media-relations/EdImpact.pdf Accessed: Jan 2015.

13. American Association of Colleges of Nursing. Enrollment growth slows at U.S. nursing colleges and universities in 2007 despite calls for more registered nurses. From: www.aacn.nche. edu/news/articles/2007/enrl Accessed: Jan 2015.
14. World Health Organization. WHO nursing and midwifery progress report 2008-2012. From: www.who.int/hrh/nursing_midwifery/ NursingMidwiferyProgressReport.pdf Accessed: Jan 2015.

15. American Association of Colleges of Nursing. The baccalaureate degree in nursing as minimal preparation for professional practice. J Prof Nurs 2001; 17:267-9. doi: 10.1053/ jpnu.2001.26300

16. Institute of Medicine. The Future of Nursing: Leading change, advancing health. Washington DC, USA: The National Academic Press, 2011. Pp. 163-219.

17. Orsolini-Hain L. Mixed messages: Hospital practices that serve as disincentives for associate degree-prepared nurses to return to school. Nurs Outlook 2012; 60:81-90. doi: 10.1016/j. outlook.2011.05.007.

18. Aiken LH, Clarke SP, Cheung RB, Sloane DM, Silber JH Educational levels of hospital nurses and surgical patient mortality. JAMA 2003; 290:1617-23. doi: 10.1001/ jama.290.12.1617.

19. Friese CR, Lake ET, Aiken LH, Siber JH, Sochalski J. Hospital nurse practice environments and outcomes for surgical oncology patients. Health Serv Res 2008; 43:1145-63. doi: 10.1111/j.1475-6773.2007.00825.x.

20. Blegen MA, Goode CJ, Park SH, Vaughn T, Spetz J. Baccalaureate education in nursing and patient outcomes. J Nurs Adm 2013; 43:89-94. doi: 10.1097/NNA.0b013e31827f2028.

21. Megginson LA. RN-BSN education: 21st century barriers and incentives. J Nurs Manag 2008; 16:47-55. doi: 10.1111/j.13652934.2007.00784.x.

22. Boylston MT, Peters MA, Lacey M. Adult student satisfaction in traditional and accelerated RN-to-BSN programs. J Prof Nurs 2004; 20:23-32. doi: 10.1016/j.profnurs.2003.12.008.

23. McEwen M, White MJ, Pullis BR, Krawtz S. Essential content in RN-BSN programs. J Prof Nurs 2014; 30:333-40. doi: 10.1016/j. profnurs.2013.10.003.

24. Conner NE, Thielemann PA. RN-BSN completion programs: Equipping nurses for the future. Nurs Outlook 2013; 61:45865. doi: 10.1016/j.outlook.2013.03.003.

25. National League for Nursing Board of Governors. Academic progression in nursing education: A living document from the national league for nursing. From: www.nln.org/docs/ default-source/about/nln-vision-series-(position-statements)/ nlnvision 1.pdf?sfvrsn=4 Accessed: Jan 2015.

26. Allen PE, Armstrong ML. RN-BSN curricula: Designed for transition, not repetition. J Prof Nurs 2013; 29:e37-42. doi: 10.1016/j.profnurs.2013.06.001.

27. Boylston MT, Jackson C. Adult student satisfaction in an accelerated RN-to-BSN program: A follow-up study. J Prof Nurs 2008; 24:285-95. doi: 10.1016/j.profnurs.2007.10.006.

28. Robertson S, Canary CW, Orr M, Herberg P, Rutledge DN. Factors related to progression and graduation rates for RN-tobachelor of science in nursing programs: Searching for realistic benchmarks. J Prof Nurs 2010; 26:99-107. doi: 10.1016/j. profnurs.2009.09.003.

29. Cangelosi PR. The tact of teaching RN-to-BSN students. J Prof Nurs 2004; 20:267-73. doi: 10.1016/j.profnurs.2004.04.002.

30. Delaney C, Piscopo B. There really is a difference: Nurses experience with transitioning from RNs to BSNs. J Prof Nurs 2007; 23:167-73. doi: 10.1016/j.profnurs.2007.01.011.

31. Al-Riyami AA, Afifi M. Determinants of women's fertility in Oman. Saudi Med J 2003; 24:748-53.

32. Varghese T. Women empowerment in Oman: A study based on Women Empowerment Index. Far East J Psychol Bus 2011; 2:37-53.

33. Oman Ministry of Health. The 8th five-year plan for health development (2011-2015). From: www.nationalplanningcycles. org/sites/default/files/country_docs/Oman/five_year_plan for_health_development_2011-2015.pdf Accessed: Jan 2015 